http://jmscr.igmpublication.org/home/ ISSN (e)-2347-176x ISSN (p) 2455-0450 crossref DOI: https://dx.doi.org/10.18535/jmscr/v8i4.05

\title{
Telescopic Nail in Osteogenesis Imperfecta Early Experience in Nitor
}

Authors

\section{Dr R.A.M. Kausarul Islam ${ }^{\text {** }}$, Dr Zahid Ahmed², Dr Malay Kumar Saha ${ }^{3}$, Dr Ripon Kumar Roy ${ }^{4}$, Dr Md. Mizanur Rahman ${ }^{5}$, Dr Golam Faruque}

${ }^{1}$ Assistant Professor, Orthopedic Surgery Department, NITOR, Dhaka, Bangladesh

${ }^{2}$ Assistant Professor, Orthopedic Surgery Department, NITOR, Dhaka, Bangladesh

${ }^{3}$ Associate Professor, Orthopedic Surgery Department, Mymensingh Medical College \& Hospital,

Bangladesh

${ }^{4}$ Assistant Register, NITOR, Orthopedic Surgery Department, Dhaka, Bangladesh

${ }^{5}$ Assistant Professor, Orthopedic Surgery Department, Faridpir Medical College \& Hospital, Bangladesh

${ }^{6}$ Professor (Retired), Orthopedic Surgery Department, NITOR, Dhaka, Bangladesh

*Corresponding Author

\section{Dr R.A.M. Kausarul Islam}

\section{Abstract}

Paediatic long bone lesions often need to be fixed or stabilized as a part of the treatment. But difficulties arise due to the bone is growing on. Osteogenesis Imperfecta is a genetic disorder that mainly affects the bone. It results in bones that break easily \& deformed. It has no cure. The incidence ratio of OI is 1:20000 to 1:50000 live births. For many years, Surgical Correction of deformities, physiotherapy and the use of orthotic support devices were the primary treatment. Intramedullary Fixation with the use of Telescopic Rod is one of the Standard Methods for long bone Stabilization in Growing children with Osteogenesis Imperfecta. Surgical Technique, Preoperative Radiographs are thoroughly evaluated to assess the deformity \& to estimate the length and diameter of the Rods to be used. However, for severely angulated limb segments, we determined the Rod length intra-operatively, after performing multiple Osteotomies. From June 2016 to June 2018 in NITOR, we managed 9Tibiae 6 Femur by Telescopic Nail at the age of 2 to 12 years.

Keywords: Telescopic Nail, Osteogenesis Imperfecta, Surgical Technique, Preoperative Radiographs.

\section{Introduction}

Osteogenesis imperfecta is an autosomal dominant or recessive connective tissue disorder caused by the deficiency of Type I collagen production associated with the deficiency of collagen Type I alpha 1 chain and collagen Type I alpha 2 chains. This disease causes problems altogether tissues that contain Type 1 collagen. In addition to several systemic problems like blue sclerosis, otosclerosis, cardiac diseases, elasticity within the joint and thinning of the fascia, it also causes the loss of the normal ossification of the endochondral bone. ${ }^{1}$ This results in easily fragile bones. Osteogenesis imperfecta may be a genetically determined pathology that suggests bone variability and osteoporosis with early onset of fractures after low energy trauma. ${ }^{2}$ The 2 main genes involved are COL1A1 and COL1A2 and 


\section{JMSCR Vol||08||Issue||04||Page 26-30||April}

therefore the mutations are transmitted recessively, dominant or appear spontaneously and affect the synthesis of type one collagen during a quantitative, qualitative, or mixed way. ${ }^{3}$ For a far better understanding of the clinical problems, Sillence and Danks created a classification that originally had 4 groups but continued to feature more and more subclasses because the genetic study evolved progressing up to type XI. ${ }^{4,5}$ Today, telescopic nails with elastic or extendable features frequently resort. The elastic telescopic nails work as a drag of retraction over time, while the matter encountered the necessity to open the joint during fixation to prevent migration, which posed another challenge. $^{6-8}$

\section{Materials and Method}

The study group consisted of 15 patients both males and females, with ages ranging from 2 to 12 years. The male: female ratio was 1:2. All patients had low trauma oslongum fractures. The femur is foremost involved prior to the diagnostic. The mean number of oslongum fractures was 3, counting both upper and lower extremities. Every patient who was diagnosed was immediately introduced to the bio phosphonates protocol. Regarding the silence classification, 9 patients were grouped as type III, 3 patients as type IVA and rest 3 patients as IB. All of them had only an orthopedic treatment before surgery.

\section{Results}

Table 1: Patients Diagnosis History \& Status at a Glance

\begin{tabular}{||l||c|c|c|c|c|c||}
\hline Type & Inheritance & $\begin{array}{c}\text { Bone } \\
\text { fragility }\end{array}$ & $\begin{array}{c}\text { Deformity of } \\
\text { long bones }\end{array}$ & $\begin{array}{c}\text { Growth } \\
\text { retardation }\end{array}$ & Spine & Incidence \\
\hline \hline IA & $\begin{array}{c}\text { Autosomal } \\
\text { dominant }\end{array}$ & $\begin{array}{c}\text { Flexible, } \\
\text { less severe } \\
\text { than } \\
\text { typically }\end{array}$ & Functional & Short build & $\begin{array}{c}\text { Scoliosis and } \\
\text { kyphosis in 20\% }\end{array}$ & $1 / 30.000$ \\
\hline \hline IB & $\begin{array}{c}\text { Autosomal } \\
\text { dominant }\end{array}$ & $\begin{array}{c}\text { Flexible, } \\
\text { less severe } \\
\text { than } \\
\text { typically }\end{array}$ & Functional & Short build & $\begin{array}{c}\text { Scoliosis and } \\
\text { kyphosis in 20\% }\end{array}$ & $1 / 30.000$ \\
\hline \hline II & $\begin{array}{c}\text { Autosomal } \\
\text { recessive }\end{array}$ & $\begin{array}{c}\text { Very } \\
\text { extreme }\end{array}$ & Crumbled bone & Unknown & - & $1 / 62.000$ \\
\hline \hline III & $\begin{array}{c}\text { Autosomal } \\
\text { recessive }\end{array}$ & severe & $\begin{array}{c}\text { Progressive } \\
\text { bowing of the } \\
\text { long bone }\end{array}$ & $\begin{array}{c}\text { Severe, } \\
\text { smallest of all } \\
\text { patients }\end{array}$ & kyphoscoliosis & Very rare \\
\hline \hline IVA & $\begin{array}{c}\text { Autosomal } \\
\text { dominant }\end{array}$ & Moderate & Functional & Short build & kyphoscoliosis & unknown \\
\hline \hline IVB & $\begin{array}{c}\text { Autosomal } \\
\text { dominant }\end{array}$ & Moderate & Functional & Short build & kyphoscoliosis & unknown \\
\hline
\end{tabular}

Due to several factures, rapid bone demineralization causes of a patient. Axial deformations of bones increased number of fractures and loss of ambulation. The only treatment for these cases was Surgery. Fieldmiller corrective osteotomies and Fassier-Duval are two telescopic nail osteosynthesis methods. Prior to the surgical intervention, patients had a bisphosphonate treatment. The necessity for such aggressive surgical treatment is given by the rapidly evolving anterior bowing. SheffieldMillard osteotomies are approximately 200 angulations narrow medullar channel, which makes solution for passing the rod. Sometimes, in very severe cases, when the distance between the epiphysis gets smaller as the bone gets more and 


\section{JMSCR Vol||08||Issue||04||Page 26-30||April}

more bowed. It is imperative to do a shorting of the segment so that the soft tissues are not put in excessive tension after alignment.

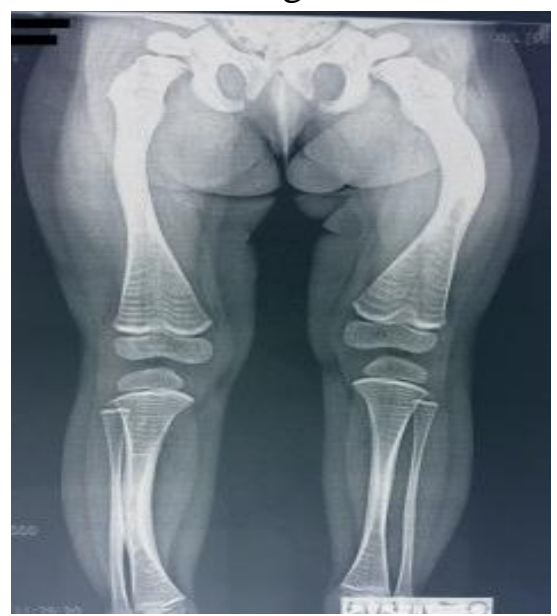

Figure 1: 3-year-old patient with long bone bowing and multiple fractures of femur

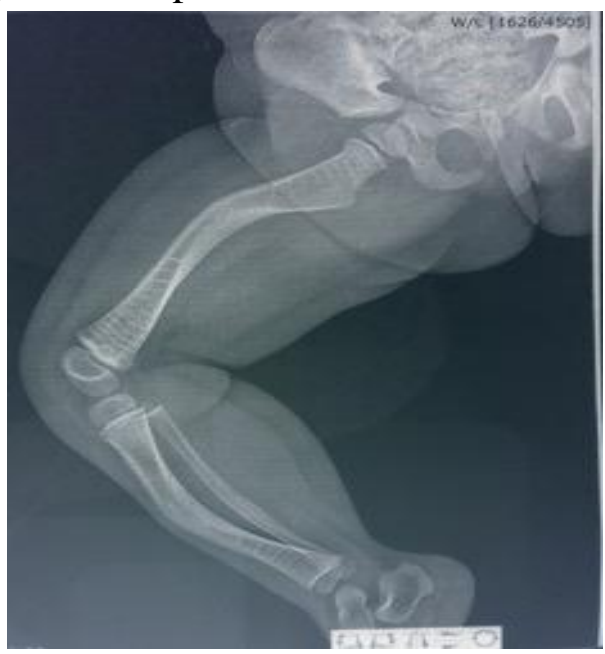

Figure 2: Right femur bowing after 2 fractures in the middle section and right tibia bowing after 3 fractures

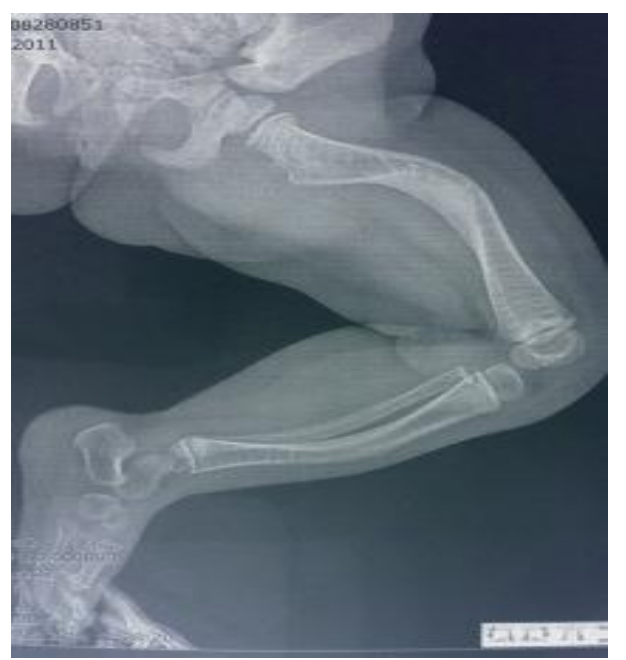

Figure 3: Left femur bowing after 3 fractures in the mid region and left tibia bowing after 2 fractures in the midpoint

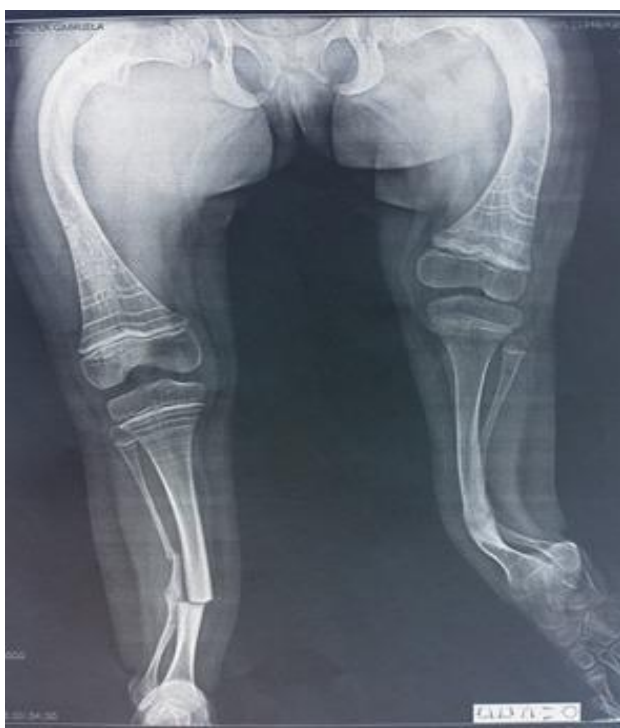

Figure 4 An 8-year-old patient with bilateral femur and tibia bowing treated orthopedically

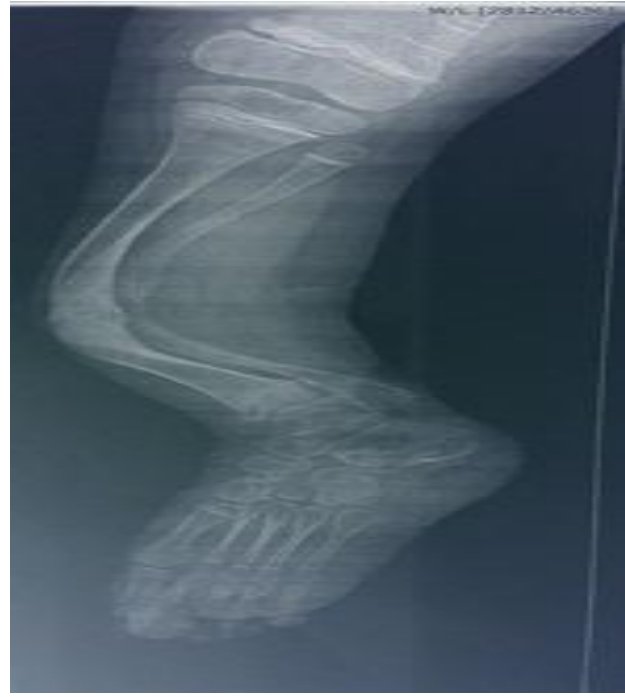

Figure 5: A 3-year-old patient with 4 fractures of the tibia and anterior bowing

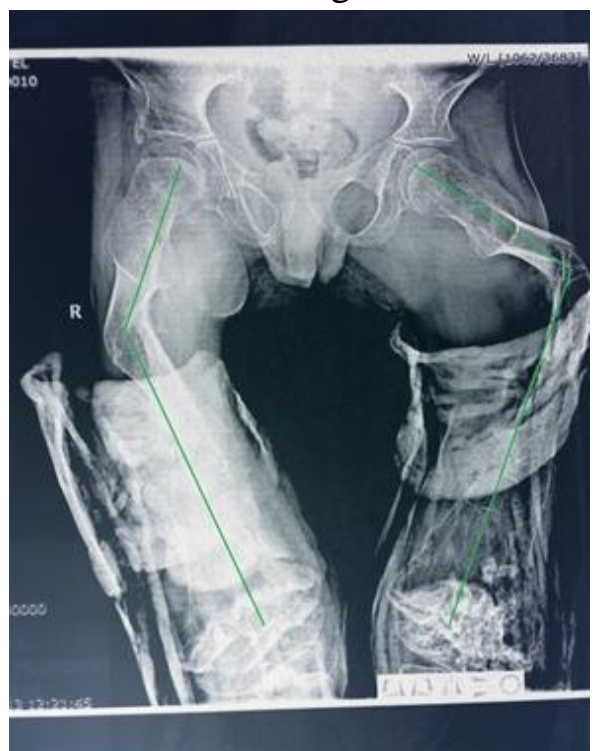

Figure 6: A 9-year-old patient with numerous femur fractures and almost $90^{\circ}$ angulation 


\section{Discussion}

The physicians used Kirschner wire ${ }^{9}$, Kuntscher nails ${ }^{10}$, Rush nails ${ }^{11}$, Ender nail and most recently elastic nailing, until development the method. ${ }^{12}$ All the techniques had good short-term results, with good bone alignment and prevention of the re-fracturing of the bone. But, the problem with these materials that patients outgrew very fast. Like secondary bowing and re-fracturing. It appeared when the growth plates went too distant from the rod and the bone outgrew the nail. Also, the low stability of the nails was a down factor, as nail loosening and slippage became a problem after the bone healed and grew in length and diameter. Regarding this fact, the first telescopic rod system was developed by Bailey and Dubow, soon after being improved to the Sheffield rod in the $\mathrm{UK}^{13-15}$. The basic goal of telescopic nailing was achieved with these new systems, meaning that one can obtain a long-lasting osteosynthesis in a growing bone that can have good long-term results and can decrease the risk of secondary fractures and bowing once the nail starts to tear and cannot be outgrown by the bone. The problem with these systems became clear when the children had to start moving after the surgery and the extensive soft tissue damage to the joint surface and capsule became an evident impending movement. These proved to be a problem as joint stiffness and pain prolonged the postoperative recovery period with a decrease in life quality and ambulation. This telescopic rod achieves this by giving the operator the opportunity to insert the components in the distal epiphysis under $\mathrm{Rx}$ control so that the growth plate takes minimal damage and the joint surface is protected. ${ }^{16}$

\section{Conclusion}

Telescopic nails methods reduced the rate of reoperation from $51 \%$ to $27 \%$. This difference is less noticeable in the long term due to mechanical complications and secondary joint problems. The healing of the bone and rigid system gives the kid the chance to possess a traditional life without the danger of secondary fractures that would damage the nail and demand a second surgical intervention. The goal of the telescopic rod is to offer the right solution for the Osteogenesis imperfecta patient to possess a traditional life without the permanent fear of getting a fracture that would mean long periods of cast immobilization or surgical interventions with uncertain results.

\section{References}

1. Forlino A, Marini JC. Osteogenesis imperfecta. Lancet 2016; 387:1657-71. Forlino A, Cabral WA, Barnes AM, Marini JC. New perspectives on osteogenesis imperfecta. Nat Rev Endocrinol. 2011; 7:540-557.

2. Marini JC, Forlino A, Cabral WA, Barnes AM, San Antonio JD, Milgrom S, Hyland JC, Ko“rkko“ J, Prockop DJ, De Paepe A, et al. Consortium for osteogenesis imperfecta mutations in the helical domain of type I collagen: regions rich in lethal mutations align with collagen binding sites for integrins and proteoglycans. Hum. Mutat. 2007; 28:209-221.

3. Venturi G, Tedeschi E, Mottes M, Valli M, Camilot M, Viglio S, Antoniazzi F, Tato` L. Osteogenesis imperfecta: clinical, biochemical and molecular findings. Clinical Genetics. 2006; 70:131-139.

4. Sillence DO, Danks DM. The differentiation of genetically distinct varieties of osteogenesis imperfecta in the newborn period. Clin Res. 1978; 26:178.

5. Middleton RWD. Closed intramedullary rodding for osteogenesis imperfecta. J Bone Joint Surg Br. 1984; 66:652-655.

6. Cho TJ, Choi IH, Chung CY, Yoo WJ, Lee $\mathrm{KS}$, Lee DY. Interlocking telescopic rod for patients with osteogenesis imperfecta. J Bone Joint Surg Am 2007; 89:1028-35.

7. Göçer H, Ulusoy S, Çıraklı A, Kaya İ, Dabak N. Osteogenezis İmperfektalı Hastada İntramedüller Çiviile Kırıkve 
Deformite Tedavisi. Med Bull Haseki 2014; 52:126-9.

8. Lee K, Park MS, Yoo WJ, Chung CY, Choi IH, Cho TJ. Proximal migration of femoral telescopic rod in children with osteogenesis imperfecta. J Pediatr Orthop 2015; 35:178-84.

9. Joseph B, Rebello G, Chandra KB. The choice of intramedullary devices for the femur and the tibia in osteogenesis imperfecta. J Pediatr Orthop B. 2005; 14(5):311-319.

10. Mulpuri K, Joseph B. Intramedullary rodding in osteogenesis imperfecta. $\mathrm{J}$ Pediatr Orthop. 2000;20:267-273.

11. Boutaud B, Laville JM. Elastic sliding central medullary nailing with osteogenesis imperfecta. Fourteen cases at eight years follow-up. Rev Chir Orthop Reparatrice Appar Mot. 2004 Jun; 90(4): 304-311.

12. Bailey RW, Dubow HI. Studies of longitudinal bone growth resulting in an extensible nail. Surg Forum. 1963; 14:455.

13. Karbowski A, Schwitalle M, Brenner R, Lehmann H, Pontz B, Worsdorfer O. Experience with Bailey-Dubow rodding in children with osteogenesis imperfecta. Eur J Pediatr Surg. 2000; 10:119-124.

14. Ferrat P, Hefti F. The interlocking telescopic tibial nail avoids damage to the ankle joint in osteogenesis imperfect 23rd European Pediatric Orthopaedic Society meeting, Geneva. 2004 Apr 1

15. Ruck J, Dohan-Oliel N, Montpetit K, Rauch F, Fassier F. Fassier Duval femoral rodding in children with osteogenesis imperfecta receiving bisphosphonates: functional outcomes at one year. J Child Orthop. 2011; 5(3):217-224.
16. Ruck J, Dohan-Oliel N, Montpetit K, Rauch F, Fassier F. Fassier Duval femoral rodding in children with osteogenesis imperfecta receiving bisphosphonates: functional outcomes at one year. J Child Orthop. 2011; 5(3):217-224. 